ISSN: 2174-5609

DOI. https://doi.org/10.14198/INTURI2022.23.11

Tin Investigaciones

$\triangle$ S TURISTICAS

Cita bibliográfica: Manzano Insuasti, P.R.y Silva, E. (2022). A joint analysis of service quality: a case study of SERVQUAL and INTSERVQUAL models in Ecuadorian lodges. Investigaciones Turísticas (23), pp. 239-265. https://doi.org/10.14198/INTURI2022.23.11

\title{
A joint analysis of service quality: a case study of SERVQUAL and INTSERVQUAL models in Ecuadorian lodges
}

Un análisis conjunto de la calidad del servicio: un estudio de caso de los modelos SERVQUAL e INTSERVQUAL en lodges ecuatorianos

Pablo Raúl Manzano Insuasti (iD) Universidad Anáhuac de México, México pablo.manzano@anahuac.mx

Eliud Silva (iD) Universidad Anáhuac de México, México jose.silva@anahuac.mx

\section{ABSTRACT}

The main objective of this document is to combine and analyze, from a statistical perspective, the expectations and perceptions of the quality of service of national and foreign tourists staying in lodge-type hotels through the so-called SERVQUAL model. We also seek to study the employees who work in these companies, using the INTSERVQUAL model. The study has been conducted among establishments located in the Sierra and Amazon of Ecuador. Statistical tools such as Principal Component Analysis (PCA) and correlations are used. The main findings coincide with the existing results in the specialized literature. Significant new correlations have been identified and indices for each of the cases addressed have been estimated, all of them with a high explanatory capacity. These indices are considered as a means to facilitate decision-making in order to improve the quality of the service in the lodges under study.

Keywords: Expectations; perceptions; lodge; quality; service; SERVQUAL; INTSERVQ

\section{RESUMEN}

El objetivo principal de este documento es combinar y analizar, desde una perspectiva estadística, las expectativas y percepciones de la calidad de servicio de los turistas nacionales y extranjeros alojados en establecimientos de categoría lodge a través del llamado modelo SERVQUAL, así como el de empleados que laboran en estas empresas, a través del modelo denominado INTSERVQUAL. El estudio se realiza en establecimientos ubicados en la Sierra y Amazonia del Ecuador. Se utilizan algunas herramientas estadísticas como Análisis de Componentes Principales y correlaciones. Los hallazgos más significativos son la concordancia 
con los resultados existentes en la literatura especializada y la identificación de nuevas correlaciones significativas, así como la estimación de índices para cada uno de los casos abordados, todos ellos con una alta capacidad explicativa. Estos índices se consideran un medio para facilitar la toma de decisiones en beneficio del mejoramiento de la calidad del servicio en los establecimientos objeto de estudio.

Palabras clave: Expectativas; percepciones; lodge; calidad; servicio; SERVQUAL; INTSERVQUAL

\section{INTRODUCTION}

Ecuador has an area of $267,370 \mathrm{~km}^{2}$, its geography consists of 4 regions: Coast, Sierra, Amazon and Insular or Galapagos. As for the peculiarity of its tourist destinations, it is worth mentioning: its proximity, its gastronomic variety, its multiculturalism and its mega-diversity. It is considered that these elements generate an attractive scenario for the dynamization of tourism both internally and externally. Faced with these characteristics, the continuous growth of the demand to know Ecuador has evolved in an increasing way, extending the offer of services to exclusive markets and with specific needs. Within this evolution, the hotel sector has presented a notable change to capture these markets, focusing its objective on improving service quality.

The increase in visits to the country was the result of the promotional campaign carried out by the Ministry of Tourism (MINTUR) internationally. With a duration of 32 months, from April 2014 to November 2016, and with the slogan "All you need is Ecuador". This allowed the hotel and restaurant sector, in the 4 regions, to obtain substantial profits. In fact, the recategorization of hotel establishments has influenced a more exclusive selection by potential clients. The presence of new categorizations and their services have segmented the scales of market demands, being the presence of the concept of lodge, resort, shelter, tourist farm, tourist camp and customer house, the new concepts adhered to the Tourism Accommodation Regulation, issued by the Ministry of Tourism (MINTUR, 2015).

The new types of accommodation establishments, contemplated in the Tourism Accommodation Regulation, are explicit in relation to their description, classification, categorization and registration process; however, the perception of quality by the consumer and the proper administration of these establishments have not gone hand in hand, as expected, to create competitiveness in the continuous evolution of tourism activity. The need for managers and investors to recognize the importance of improving the quality of service that becomes the main competitive advantage remains (Nadiri and Hussain, 2005).

The evaluation of the quality of service has complex aspects to be measured in comparison with the products, focusing on its intrinsic nature of heterogeneity, inseparability of production and consumption, perishable and intangible (Frochot and Hughes, 2000). In Ecuador, this problem is not foreign to the reality that exists in hotel establishments, in which the empirical evaluation of the quality of service and its low relationship with the expectations and perceptions of the client, provide superficial results that still become useful for continuous service improvement.

The current quality measurement system carried out by the Ministry of Tourism of the country includes a scheme focused on corporate social responsibility, intrinsically valuing the hotel sector; likewise, it rejects the needs and / or experiences that the client may perceive 
about the service provided, so that the evaluation of the quality of service presents certain gaps, focused on evaluating criteria of tangibility, reliability, responsiveness, assurance and empathy, which are key axes when determining the quality of a service. This paper emphasizes its importance for which this study emphasizes its importance in reducing the existing gap between qualitative and quantitative studies inherent to the quality of the hotel service, which limit the improvement of the hotel offer and stop its continuous growth.

That is why, for this study to analyze the reduction of existing gaps for the measurement of service quality, the use of the SERVQUAL and INTSERVQUAL models have been considered. On one hand, the first was named as such by its authors Parasuraman et al., $(1985,1988)$ for measuring service quality externally (customers). On the other hand, the INTSERVQUAL model was proposed by Frost and Kumar (2000) to measure service quality internally (employees).

The Ecuadorian service quality measurement system has a purely qualitative line of analysis, the same being the only exogenous element that guides on the characteristics of lodging; therefore, it is considered that a quantitative criterion is necessary, which is usually ignored when making a comprehensive evaluation in the measure of quality of service. In this sense: How different are the correlations of the variables of the questionnaires applied in the selected lodges based on what exists in the literature, and, how feasible it is to estimate indices through Principal Component Analysis with a high explanatory capacity?. So, our aim is to combine and analyze with a statistical approach the expectations and perceptions of the quality of service of national and foreign tourists staying in lodge category hotels, using both the SERVQUAL and the INTSERVQUAL models.

Since our approach, this paper brings new to literature the following. At first, we consider an integral perspective when both SERVQUAL and INTSERVQUAL models are jointly applied. Secondly, these models will be used in the case of lodges category hotels. And finally, this research will have a particular context in Latin America (Ecuador), which is a region that has no studies regarding these specialized terms. Thereby, it is believed that this set of particularities justify a significant contribution.

This research has an unpublished character, as it is carried out for the lodges category in Ecuador and tends to be a referential axis for the statistical application in a joint analysis where it is possible to show results generated through the selected models. In order to pursue this aim, a quantitative method was applied which was developed based on the employed questionnaires, analyzed through correlations to compare with previous results or point out new findings and estimate Principal Components to generate indices and to decode its meaning.

The document is organized as follows. A background section presents the relevant literature related to the quality of service, its conceptual models and existing empirical studies. Later, the methodology to be used to achieve the planned objectives is specified, the type, design and instruments to be applied, the way in which the sample was chosen and the statistical techniques used are briefly explained. In the fourth part, the results are shown, based on correlations and Principal Component Analysis (PCA), where indices of service quality measurement in this hotel category are identified. In the last section, conclusions and suggestions are drawn up, based on the information obtained and future lines of research are raised. 


\section{II.BACKGROUND}

The quality of service is considered as a critical determinant of competitiveness (Lewis, 1989), which allows an organization to differentiate itself from another and through it obtain a lasting competitive advantage (Moore, 1987); it characterizes its level of associativity to three conditions inherent to services: intangibility, inseparability of production and consumption and heterogeneity (Zeithaml et al., 1985). The quality of service includes a multidimensional concept linked to customer expectations (Grönroos, 1984) where it is also defined as the result of comparing between expectations and perceptions of the service providers, whose result seeks to respond to the expectations of the client on a consistent basis (Lewis and Booms, 1983). This definition is framed within the paradigm of disconfirmation relating to satisfaction studies (Thibaut, 2017; Cardozo, 1965; Anderson, 1973); therefore, it is suggested that the quality of service is the difference between expected and perceived service.

The measurement of quality of service is a fundamental factor in establishing levels of customer satisfaction. The quality measurement process makes it possible to identify the differences between the expectations and perceptions of the client against a service, whose potential results are at a satisfactory, ideal or unacceptable level; for this, the complexity of their analysis leads to the approach of several models generated by different authors, whose purpose is to reduce these differences. Parasuraman et al. (1985) propose the SERVQUAL model, where the quality of service corresponds to a function of the differences between expectations and performance of the quality dimensions. Their model is structured based on a gap analysis; these being visualized as follows:

Gap 1: difference between consumer expectations and managers' perceptions of those expectations. Example. Ignorance about consumer expectations.

Gap 2: difference between the perception of the administrators of the expectations of the consumers and the specifications of the quality of service. Example. Unsuitable standards of quality of service.

Gap 3: difference between service quality specifications and currently delivered service. Example. Service performance gap

Gap 4: difference between the service delivered and the communication to consumers about the service delivered. Example. Do the promises match the delivery?

Gap 5: difference between consumer expectations and perceived service. This gap depends on the size and direction of the 4 gaps associated with the delivery of the quality of service on the market side.

According to this model, the quality of service is a function of perception and expectations, which is modeled as

where

$$
S Q=\sum_{j=1}^{k}\left(P_{i j}-E_{i j}\right)
$$

$S Q=$ service quality;

$\mathrm{k}=$ number of attributes;

$P_{i j}=$ performance of perceptions of incentives $i$ and with respect to attributes $j$;

$E_{i j}=$ quality of service expectations for attributes $j$ which is a relevant standard for incentives $i$. 
Several studies have applied the SERVQUAL model, to measure the quality of service in hotels and their various approaches. In general, service expectations are compared among business and leisure visitors (Heung and Wong, 1997) whose results show a difference between levels of service expectations between business and leisure travelers, which managers should address them consequently; the quality of service perceived in European customers on the island of Cyprus is analyzed (Nadiri and Hussain, 2005) where its results reveal that tangibles and intangibles dimensions have a meaningful positive effect in European travelers; expectations and perceptions of the quality of service of hotels in Malaysia are evaluated through the comparison between domestic clients (Mey et al., 2006) demonstrating that the hotel guests' perceptions of service quality provided by the hotel industry were lower than their expectations; discrepancies between perceptions and expectations in hotels in Santa Catalina, Brazil are calculated (Stefano et al., 2015) whose results express that the services in these hotels have many gaps to be improved.

The difference between expectations and perceptions of the service in hotels of Bengaluru, India (Sunil et al., 2018) is valued, demonstrating that quality is in stable and it is perceived differently by various customers; the perceptions of international tourists and the expectations of quality of service in the Chinese hotel industry are discussed (Qu and Tsang, 1998) where 22 significant service gaps were found and the 'staff skill and performance' and 'extra amenities provided' were the most valuable tourists' choice decision; the service quality gap between the hotels in Saudi Arabia and outside the Middle East is evaluated (Qarashia, 2018) where its findings can serve as a reference for elevating the image of hotels in Saudi Arabia; the benefits of applying a measure system to benefit the service quality provided by hoteliers in Penang (Malaysia) is demonstrated (Mola and Jusoh, 2011) where negative and positive scores of items analyzed could determine that the guests' perceived value of the service is less than their expectations based on measured variables; and the difference between the level of perceived and expected service quality was concluded in foreign tourists visiting Turkish Republic of North Cyprus (Ertürk, 2019), concluding that, through an statistical analysis, the level of perceived service quality was below the level of expected service quality.

Other researches related to the application of the SERVQUAL model are evidenced in the restaurant industry (Kahl et al., 2019; Górka-Chowaniec, 2018), theme parks (Tsang et al., 2012; Albattat and Romli, 2017; Chan et al., 2019; Fotiadis and Vassiliadis, 2016); museums (Nowacki, 2005; Markovic et al., 2013); and sport tourism industry (Kouthouris and Alexandris, 2005; Doone, 2009; Shonk and Chelladurai, 2008), which is denoted that the benefits of using this model make it possible to identify and reduce the existing gaps between expectations and perceptions of the quality of services in different hotel, tourism and food business modalities.

Frost and Kumar (2000) propose an internal service quality model based on the concept of the GAP model (Parasuraman et al., 1985), which they called INTSERVQUAL. This model evaluates the dimensions, and their relationships, that determine the quality of service between employees (front-office staff) and suppliers (support staff), within a service organization. Gap 1 represents the difference between the perception of support staff (internal provider) and the expectations of front-office staff (employees). The Gap 2 is the difference between the service quality specifications and the service delivered, resulting in an internal service performance gap. Gap 3 corresponds to the difference between the expectations of the front-office staff and the perceptions of the quality of service of the support staff (internal provider). 
Applications of the INTSERVQUAL model (Frost and Kumar, 2000) have been made in the hotel industry from the employee's perspective; this is what White and Rudall (1999) refer to through their study on measuring the internal quality of service in the Australian hotel industry, revealing that the construct of SERVQUAL model was more appropriated in conceptualizing and measuring internal service quiality; Wittmer (2005) includes the cultural construct in his study to analyze the internal service in the Swissôtel hotel chain in Switzerland, Singapore, and Australia, concluding that managers should handle a system of framework with which they can check multicultural internal service quality based on multicultural service expectations; Al-Ababneh (2015) focused on measuring the quality of internal service by comparing four and five star hotels in Jordan, its findings revealed that, from the employees' perspective, the service quality of five-star hotels in Jordan was higher than that of four-star hotels.

Ntavitavian (2020) exposed in his research an overall image of the performance of a five-star hotel business through its financial indicators, as well as through the customer and the employee satisfaction. Its results showed that the employees seemed less satisfied with variables of payment and training opportunities, and the total score satisfaction was differentiated between the employees' age groups and work departments. Chen (2013) in his research concludes that the internal service quality at international tourist hotels is influenced directly by a bureaucratic organizational culture and transformational leadership. Other studies referring to the INTSERVQUAL model have been developed to measure the internal quality of service in catering and restaurant industries (Moussa et al., 2012; Bourata et al., 2009; Kim, 2014) as well as other areas considered, which involves a B2B environment in the petrol industry (Pantouvakis, 2011) and electronic government services (Yeh and Chu, 2009).

\section{METHODOLOGY}

\subsection{Questionnaires}

The aforementioned questionnaires are applied in lodge category hotels of the Sierra and Amazon of Ecuador, which are considered representative of their class in the country. It was decided not to make pilot survey and test about validity and reliability over the questionnaires given that they are previously tested instruments (Parasuraman et al., 1985; Frost and Khumar, 2000), from which were changed the word "hotel" by "lodge". Likewise, the sample was taken from the tourists who visit the lodges through a simple random sampling.

According to the instruments used, the variables, dimensions and scale that comprise them are described in the questionnaires. In a first instance, a questionnaire for national and foreign tourists, based on the SERVQUAL model is proposed, and subsequently, the lodge's employees questionnaire scale, based on the INTSERVQUAL model is exposed. It is worth mentioning that the instrument for national tourists was translated into Spanish for purposes of better understanding by the respondents and for practical aims, its validity was assumed equivalent. Detailed instruments for both models are found in Annexes.

\subsection{Sample size}

To define the sample size, we have that the registered dynamic of total guests for the period 2012-2016 in the two selected lodges for every region is as follows: 
Table 1. Total guests for the period 2012-2016 in the selected lodges

\begin{tabular}{|c|c|c|c|c|c|c|c|c|c|c|c|c|c|}
\hline \multirow[t]{2}{*}{ Region } & \multirow[t]{2}{*}{ Lodge } & \multicolumn{2}{|c|}{2012} & \multicolumn{2}{|c|}{2013} & \multicolumn{2}{|c|}{2014} & \multicolumn{2}{|c|}{2015} & \multicolumn{2}{|c|}{2016} & \multicolumn{2}{|c|}{$\begin{array}{c}\text { Global } \\
\text { average of } \\
\text { guest }\end{array}$} \\
\hline & & $\mathrm{N}$ & $\mathrm{F}$ & $\mathrm{N}$ & $\mathrm{F}$ & $\mathrm{N}$ & $\mathrm{F}$ & $\mathrm{N}$ & $\mathrm{F}$ & $\mathrm{N}$ & $\mathrm{F}$ & $\mathrm{N}$ & $\mathrm{F}$ \\
\hline \multirow{2}{*}{ Sierra } & Black Sheep Inn & 490 & 632 & 176 & 521 & 390 & 743 & 364 & 401 & 221 & 903 & 408 & 686 \\
\hline & $\begin{array}{l}\text { Dream Garden } \\
\text { Lodge }\end{array}$ & 201 & 570 & 196 & 475 & 511 & 796 & 410 & 835 & 378 & 653 & 339 & 666 \\
\hline \multirow{2}{*}{ Amazonía } & Shandia & 706 & 1050 & 415 & 843 & 602 & 842 & 572 & 673 & 498 & 731 & 559 & 828 \\
\hline & $\begin{array}{l}\text { Yarian } \\
\text { Lodge }\end{array}$ & 366 & 803 & 589 & 752 & 603 & 451 & 203 & 344 & 276 & 693 & 407 & 609 \\
\hline
\end{tabular}

$\mathrm{N}$ : nationals, F: foreigners

Own elaboration

So, for practical aims, the global average guest for this period is considered as the objective population size $(\mathrm{N})$, both national and foreigners, respectively. According to Table 1 the sample size $(n)$ was estimated using (2), with a confidence level of $95 \%$ and a margin of error of $5 \%$,

$$
n=\frac{N Z_{a}^{2} p q}{d^{2}(N-1)+Z_{a}^{2} p q}
$$

where $\mathrm{Z}$ is the 95th percentile of a standard normal distribution; $\mathrm{p}$ the probability of the interview being accepted (50\%); $q=1-p$; $d$ the margin of error $(2.5 \%$ and $3.3 \%$ respectively). It should be noted that to obtain a $2.5 \%$ margin of error with foreign tourists, a sample size of 474 subjects was required, which was difficult to achieve due to logistics, so the margin of error for this segment was adjusted to $3.3 \%$. In short, the sample sizes were 308 and 305 for national and foreigners, respectively. In the case of employees, the total population of each lodge was used, under the criterion of inclusion of all those who had an annual contract. Thereby, the sample size was 89 for employees. The questionnaires were applied to national tourists from February 6th to 9th, and, from March 25th to 27th, 2016 (dates that corresponded to the Carnival and Easter holidays respectively in the Ecuador), and the first three bimesters of the year for foreign tourists and employees.

About the sampling bias we discard self-selection because the tourists were selected randomly meanwhile the employees as a whole set. Regarding undercoverage, we collected data samples from the lodges that were accessible and where all tourists and employees had the same probability to be chosen, that is why the results are addressed just to a particular case study. As regards the non-response bias, we minimized it using well-designed instruments SERVQUAL and INTSERVQUAL and they were applied to the right audience. With regards pre-screening bias, we did not employ selection criteria that could discourage some persons from taking part in the surveys. We admit survivor bias given that we ignore certain members of the study population due to a lack of visibility, for instance disabled persons; in fact, we just focus on the current tourists and active employees in touch with the selected lodges.

It is important to recognize that could have a bias, given that the first author was the responsible to apply the surveys both national and foreigner visitors. However, it is considered that this situation does not impact in general in the answers given that there was not an encouragement or reward for answering the survey, that is, each of the participants did so 
voluntarily and at the time that seemed best to them. It was noticed to the interviewees the importance of knowing their expectations and perceptions to improve the quality of service. That is why, it is appreciated that the eventual bias committed is insignificant and does not alter the sense of the responses received.

\subsection{Statistical tools: Correlations and Principal Component Analysis (PCA)}

It is known that a correlation allows to investigate the relationship of two variables, demonstrated its strength and meaning. They are used to quantify and assess the statistical significance between the results of the variables captured in the instruments applied, both to contrast them with the results of previous studies and to find new relationships. It should be aware that several approaches have been suggested to translate the correlation coefficient into descriptors like for example "weak", "moderate" or "strong" relationship, whose cutoff points could be arbitrary (see Schober et al., 2018). We decided to avoid use them and just report the respective significant correlations. In all cases, given the no normality, the Spearman correlation was employed.

The PCA proposed by Pearson (1901) and developed by Hotelling (1933), allows to generate new set of uncorrelated variables $(m)$ starting from an observed set of variables $(p)$. The new set of variables $m(<p)$ are called Principal Components (Villardón, 2002) and they are a linear combination from the original variables. These new variables imply the so-called reduction of the dimension, where each one represents a Principal Component (Abdi and Williams, 2010).

In general, the objectives of the PCA are: a) to extract the most important information from a data set; $b$ ) compress the size of the data set, conserving the extracted information; $c$ ) simplify the description of the data set and d) analyze the structure of the observations and the variables (Abdi and Williams, 2010). For more details see for example Cuadras (2020). Legendre and Legendre (2012) state that the position of each observation in this new coordinate system of Principal Components is called a score and is calculated as linear combinations of the original variables. To interpret the Principal Components, the author recommends recognizing the correlations of the original variables with respect to the Principal Components.

To know the relevance of applying PCA to the variables under study, Bartlett's test (1937) verifies whether the correlation matrix is equal to that of identity (I), which is equivalent to a lack of significant correlation between the variables. Bartlett's sphericity test has the null hypothesis $H o: R=I$ and its statistic test is $\chi^{2}=-\left[n-1-\frac{1}{6}(2 v 5)\right] \ln |R|$, where $n$ is sample size; $v$ is the number of variables; $n$ is the Neperian logarithm and $R$ is the correlation matrix. If the null hypothesis is not rejected (i. e. P value $>0.05$ ), it is concluded that the variables are not correlated, therefore it is not advisable to carry out PCA. Likewise, in a complementary way the application of the KMO test is recurrent, whose objective is to relate the correlation coefficients observed between the study variables. The criterion to accept that the PCA model is significant is as follows: $\mathrm{KMO} \geq 0.9$ very good; $\mathrm{KMO} \geq 0.8$ remarkable; $\mathrm{KMO} \geq 0.7$ medium; $\mathrm{KMO} \geq 0.6$ low; $\mathrm{KMO} \geq 0.5$ very low.

\section{RESULTS}

First a brief demographic characterization of national and foreign tourists is made, as well as the occupational profile of the employees of the lodge's objects of study. Investigaciones Turísticas 
Subsequently, the main findings found after estimate Correlations and applying PCA are pointed out.

\subsection{Demographic characteristics}

With regard to national tourists who chose to obtain services in lodges in the Sierra and Amazon, it is evident that most of them come from the Sierra region (Andes) $(70.1 \%)$ followed by people from the Coast region (23.4\%); regarding occupation, $38.1 \%$ of respondents are students, a notable $19.9 \%$ and $14.7 \%$ of employees/self employee and business executives respectively. The education level of the respondents is $76.7 \%$ that touches graduates, $23.3 \%$ of tourists who are undergraduate. In relation to the age range, $36 \%$ is between 14 and 25 years old, 32.1\% corresponding to tourists between 26 and 35 years of age, of which $46.4 \%$ chose to spend a night in these establishments, without detriment of $45.4 \%$ of respondents who chose to spend 2 nights. It should be noted that, of the total respondents, $55.2 \%$ of them are male and $44.8 \%$ female.

For foreign tourists, $35.4 \%$ of respondents are US citizens, followed by $21.6 \%$ corresponding to French tourists. Of the total respondents, $47.9 \%$ are employee/selfemployed people, while $19.3 \%$ are students. Regarding their level of education, $82.5 \%$ are undergraduate, $39 \%$ of respondents correspond to the age range between 26 to 35 years, while $23.6 \%$ of foreign tourists are in the range of 36 to 45 years old. In the same way, it is said that $51.5 \%$ of tourists have spent the night in the lodges under study, while $43.6 \%$ chose to stay two nights in these establishments. Finally, $60.7 \%$ of respondents are male and $39.3 \%$ are female.

Table 2. Descriptive analysis of national and foreign tourists

\begin{tabular}{|c|c|c|c|c|c|c|}
\hline \multirow{2}{*}{\multicolumn{2}{|c|}{ Variable }} & \multicolumn{2}{|c|}{ National } & \multicolumn{2}{|c|}{ Foreigner } & \multirow{3}{*}{$\begin{array}{c}\text { Proportion test } \\
\text { p-value } \\
0.170\end{array}$} \\
\hline & & \multirow{2}{*}{$\begin{array}{c}\text { Frecuency } \\
170\end{array}$} & \multirow{2}{*}{$\begin{array}{c}\% \\
55.2\end{array}$} & \multirow{2}{*}{$\begin{array}{c}\text { Frecuency } \\
185\end{array}$} & \multirow{2}{*}{\begin{tabular}{|c|}
$\%$ \\
60.7
\end{tabular}} & \\
\hline Condor & Male & & & & & \\
\hline Gender & Female & 138 & 44.8 & 120 & 39.3 & 0.170 \\
\hline \multirow{5}{*}{ Age } & $14-25$ & 111 & 36.0 & 51 & 16.7 & $0.000^{*}$ \\
\hline & $26-35$ & 99 & 32.1 & 119 & 39.0 & 0.075 \\
\hline & $36-45$ & 73 & 23.7 & 72 & 23.6 & 0.978 \\
\hline & $46-55$ & 24 & 7.8 & 40 & 13.1 & 0.031* \\
\hline & 56 and more & 1 & 0.3 & 23 & 7.5 & $0.000^{*}$ \\
\hline \multirow{2}{*}{ Education } & Undergraduate & 72 & 23.3 & 212 & 82.5 & $0.000^{*}$ \\
\hline & Graduated & 236 & 76.7 & 45 & 17.5 & $0.000^{*}$ \\
\hline \multirow{5}{*}{ Occupation } & Employee/Self employee & 61 & 19.9 & 146 & 47.9 & $0.000^{*}$ \\
\hline & Professional & 73 & 23.8 & 19 & 6.2 & $0.000^{*}$ \\
\hline & Student & 117 & 38.1 & 59 & 19.3 & $0.000^{*}$ \\
\hline & Executive & 45 & 14.7 & 55 & 18.0 & 0.251 \\
\hline & Other & 11 & 3.6 & 26 & 8.5 & $0.010^{*}$ \\
\hline \multirow{2}{*}{ Period of stay } & 1 night & 142 & 46.4 & 157 & 51.5 & 0.183 \\
\hline & 2 nights & 139 & 45.4 & 133 & 43.6 & 0.704 \\
\hline \multirow{7}{*}{ Origin } & Coast & 72 & 23.4 & & & $0.000^{*}$ \\
\hline & Andes & 216 & 70.1 & & & \\
\hline & Amazon & 7 & 2.3 & & & \\
\hline & Galapagos & 13 & 4.2 & & & \\
\hline & US & & & 108 & 35.4 & $0.000^{*}$ \\
\hline & Europe (Germany and France) & & & 136 & 44.6 & \\
\hline & Other & & & 61 & 20.0 & \\
\hline
\end{tabular}

Note: All respondents may not be included due to data loss; * significative at $5 \%$ level; the normal aproximation may be inaccurate for small samples, that is why the Fisher's exact test was employed.

Own elaboration 
Regarding employees, 64\% corresponds to internal service providers (ISP) (support staff), while $36 \%$ are part of the front line (FL) staff (front desk, customer service). Of all respondents, $32.6 \%$ work in the cleaning department, $29.2 \%$ who work in the service/kitchen area (room service, bar, cafeteria, social areas) and $24.7 \%$ work in the reception department. As for gender, $55.1 \%$ are women and $44.9 \%$ are men. As regards the age range, $58.5 \%$ is between 21 and 40 years old, while $41.5 \%$ is greater than 40 years old, $91 \%$ of the personnel surveyed are employees while $9 \%$ correspond to managers/supervisors, who in their entirety work between 40 or less hours per week.

Table 3. Descriptive analysis of employees

\begin{tabular}{|l|l|c|c|c|}
\hline \multirow{2}{*}{\multicolumn{2}{|c|}{ Variable }} & \multirow{2}{*}{ Frecuency } & $\%$ & Proportion test \\
\hline Gender & Male & 40 & 44.9 & p-value \\
\hline & Female & 49 & 55.1 & 0.175 \\
\hline Age & $<40$ & 52 & 58.5 & $0.023^{*}$ \\
\hline & 40 and more & 37 & 41.5 & \\
\hline Workstation & Manager/Supervisor & 8 & 9.0 & $0.000^{*}$ \\
\hline & Employee & 81 & 91.0 & \\
\hline Work hours & $<40$ & 20 & 22.5 & $0.000^{*}$ \\
\hline & 40 and more & 69 & 77.5 & \\
\hline Work position & Internal service provider (ISP) & 57 & 64 & $0.000^{*}$ \\
\hline & Front-line staff (FS) & 32 & 36 & \\
\hline Department & Front desk & 22 & 24.7 & $0.000^{*}$ \\
\hline & Cleaning & 29 & 32.6 & \\
\hline & Service/Kitchen & 26 & 29.2 & \\
\hline & Marketing and sales & 12 & 13.5 & \\
\hline
\end{tabular}

Note: * significative at $5 \%$ level.

Own elaboration

\subsection{Correlations}

With regard national tourists, the highest positive Spearman correlation was 0.503 for expectations, while for perceptions it was 0.952. In fact, this result is like the one found in Saleh and Ryan (1991). Among the most significant correlations we have that: a) a lodge of excellence will give a sincere interest and priority in solving a problem of its clients (E6 and E7); b) the facilities and physical presence of the staff of a lodge of excellence will be impeccable (E2 and E3); c) a lodge of excellence will provide personalized attention and a real concern for its clients (E20 and E21); d) a lodge of excellence will provide its services while offering it, minimizing errors in the provision of the same (E8 and E9); e) a lodge of excellence will provide its service with optimal facilities and credibility (E4 and E5); f) a lodge has staff who provide personalized attention and interest (P20 and P21); g) the service of a lodge is a priority from the moment of its request (P7 and P8); h) the lodge and its employees have the best interest in providing a service understanding the specific needs of the client (P21 and P22); i) the employees of a lodge provide timely service and are always ready to help (P11 and $\mathrm{P} 21)$; and finally, j) when a lodge promises to provide a service, it fulfills it with a real interest in doing it (P5 and P6). In general, for perceptions the correlations are greater than those taken from expectations and all of them positive. 
Table 4. Summary of significant correlations (national)

\begin{tabular}{|c|c|c|c|l|}
\hline \multicolumn{2}{|c|}{ Expectations } & \multicolumn{2}{c|}{ Perceptions } & \multirow{2}{*}{ Mention in literature } \\
\hline Variables & Correlation & Variables & Correlation & \\
\hline E7 and E8 & 0.503 & P16 and P18 & 0.952 & Saleh and Ryan (1991) \\
\hline E6 and E7 & 0.490 & P20 and P21 & 0.935 & No registered \\
\hline E2 and E3 & 0.488 & P7 and P8 & 0.912 & No registered \\
\hline E20 and E21 & 0.472 & P21 and P22 & 0.910 & No registered \\
\hline E8 and E9 & 0.455 & P11 and P12 & 0.903 & No registered \\
\hline E17 and E18 & 0.448 & P16 and P17 & 0.891 & Khan and Su (2003) \\
\hline E5 and E6 & 0.444 & P19 and P20 & 0.887 & Shi and Su (2007) \\
\hline E4 and E5 & 0.438 & P5 and P6 & 0.879 & No registered \\
\hline E1 and E2 & 0.414 & P18 and P19 & 0.863 & Khan and Su (2003) \\
\hline
\end{tabular}

Own elaboration

According to the foreign tourist set, the highest correlation was 0.822 for expectations, while for perceptions it was 0.167 . This result is similar to Khan and Su (2003). Thereby, the most notable findings were: a) the employees, as well as the facilities of a lodge of excellence will always be impeccable (E3 and E4); b) a lodge of excellence will always provide a timely service free of errors (E8 and E9); c) employees of a lodge of excellence will always communicate when a service is going to be provided and will ensure that it will be without errors (E9 and E10); d) a lodge of excellence will have a sincere interest in solving a problem, trying to keep its facilities impeccable (E4 and E6); e) a lodge of excellence will always give a truthful service and keep its facilities visually pleasing (E4 and E5); f) when a lodge promises to provide a service, it does so while keeping its facilities visually appealing (P4 and P8); g) the employees of a lodge are courteous and timely in providing service (P7 and P16); h) a lodge has a real interest in providing a service with its visually attractive facilities (P2 and P21); i) the employees of a lodge provide courtesy when serving their clients, and security in the monetary transaction service (P15 and P16); and finally, j) the employees of a lodge are willing to provide assistance and generate a promise of timely service (P8 and P12).

Table 5. Summary of significant correlations (foreign)

\begin{tabular}{|c|c|c|c|l|}
\hline \multicolumn{2}{|c|}{ Expectations } & \multicolumn{2}{c}{ Perceptions } & \multirow{2}{*}{ Mention in literature } \\
\cline { 1 - 3 } Variables & Correlation & Variables & Correlation & \\
\hline E1 and E2 & 0.822 & P10 and P22 & 0.167 & Khan and Su (2003) \\
\hline E3 and E4 & 0.540 & P4 and P8 & 0.158 & No registered \\
\hline E5 and E6 & 0.525 & P16 and P18 & 0.148 & Khan and Su (2003) \\
\hline E8 and E9 & 0.478 & P7 and P16 & 0.145 & No registered \\
\hline E9 and E10 & 0.473 & P2 and P21 & 0.142 & No registered \\
\hline E4 and E6 & 0.459 & P15 and P16 & 0.129 & No registered \\
\hline E4 and E5 & 0.458 & P8 and P12 & 0.127 & No registered \\
\hline E16 and E17 & 0.456 & P5 and P11 & 0.122 & Saleh and Ryan (1991) \\
\hline E11 and E12 & 0.454 & P9 and P12 & 0.118 & Shi and Su (2007) \\
\hline
\end{tabular}

Own elaboration 
In accordance with Spearman correlation on the expectations of the quality of service in the employees that work in the mentioned lodges, it is obtained that the highest correlation is 0.609 for expectations and 0.778 for perceptions. An interesting point in this block is that no one of the correlations has been mentioned in literature. The most important correlations for expectations were: a) internal service providers understand the specific needs of their employees and treat them cautiously (E19 and E21); b) if there is a problem, the internal service provider shows sincerity in solving it in the time that he promises to do so (E6 and E8); c) if there is a problem, the internal service provider shows sincerity in solving it and provides security when employees need to make internal transactions (E6 and E15); d) the services provided by the internal service provider are true and real (E5 and E6); e) internal service providers are confident and willing to help their employees (E12 and E14); f) internal service providers are timely and always ready to help their employees (E8 and E12); g) internal service providers know the ways to treat their employees and answer all the questions generated by them (E17 and E19); h) internal service providers try not to make mistakes and provide their service in a timely manner to their employees (E5 and E9); i) internal service providers try to avoid mistakes, and if there is a problem, they resolve it in a timely manner (E6 and E9); j) the facilities and appearance of the internal service provision department must be impeccable (E2 and E3).

For perceptions the most notorious correlations were: $k$ ) internal service provider insists on staying error-free and providing timely service to its employees (P9 and P11); I) if there is a problem, the internal service provider resolves it promptly in a clear and orderly departmental environment (P4 and P6); $\mathrm{m}$ ) internal service provider delivers their service in a timely manner and as promised (P5 and P7); $\mathrm{n}$ ) the internal service provider gives its service in a prompted time and informs its employees (P8 and P10); o) the internal service provider tries to avoid making mistakes and always keeps its employees informed (P9 and P10); $P$ ) the internal service provider gives personalized and careful attention to its employees (P18 and P19); q) the internal service provider provides its service at the time it promises and avoids making mistakes during it (P7 and P9); $r$ ) the internal service provider keeps its employees informed about the service they will perform in a timely manner (P10 and P11); s) if there is a problem, the internal service provider solves it honestly and in a timely manner (P6 and P7).

Table 6. Summary of significant correlations (employee)

\begin{tabular}{|c|c|c|c|c|}
\hline \multicolumn{2}{|c|}{ Expectations } & \multicolumn{2}{|c|}{ Perceptions } & \multirow{2}{*}{ Mention in literature } \\
\hline Variables & Correlation & Variables & Correlation & \\
\hline E19 and E21 & 0.609 & P9 and P11 & 0.778 & \multirow{10}{*}{ No registered } \\
\hline E6 and E8 & 0.586 & P4 and P6 & 0.745 & \\
\hline E6 and E15 & 0.545 & P7 and P5 & 0.730 & \\
\hline $\mathrm{E} 5$ and $\mathrm{E} 6$ & 0.542 & $\mathrm{P} 8$ and $\mathrm{P} 10$ & 0.727 & \\
\hline E12 and E14 & 0.535 & $\mathrm{P} 9$ and $\mathrm{P} 10$ & 0.697 & \\
\hline $\mathrm{E} 8$ and E12 & 0.527 & P18 and P19 & 0.686 & \\
\hline E17 and E19 & 0.515 & $\mathrm{P7}$ and P9 & 0.664 & \\
\hline E5 and E9 & 0.514 & $\mathrm{P} 10$ and $\mathrm{P} 11$ & 0.650 & \\
\hline E6 and E9 & 0.497 & $\mathrm{P} 6$ and $\mathrm{P7}$ & 0.642 & \\
\hline E2 and E3 & 0.609 & & & \\
\hline
\end{tabular}


The significant correlations not registered in the literature for national and foreign tourists as well as employees imply new lines of research that could potentially be developed; for this purpose, the interpretation of each of them is presented below.

\subsection{Principal Components Analysis (PCA)}

\section{Items under each Component and Loading matrix}

There was not need to apply any rotation to estimate the Components, in fact there was not improvement in the explicative capacity. Thereby, the expression of the first Component for each group was a weighting of the original variables of all the considered items. That is why, it can be pointed that all the items E1-E22, P1-P22, and E1-P22 have a correlation with the first Component, respectively. Likewise, all the coefficients were positive between 0.415 and 0.999 . Specifically, the loadings are presented in Table 7 . So, the coefficients resulting from the first Component in each case, which are the linear combination of the original variables, are expressed below by means of the eigenvectors. It is worth to saying that when the Component is estimated just on expectations (Exp) or perceptions (Per) the linked items have a very high loads, in contrast when it is estimated jointly both expectations and perceptions (Exp-Per).

Table 7. Components extracted by groups for estimated indices

\begin{tabular}{|c|c|c|c|c|c|c|c|c|c|c|c|}
\hline \multirow{2}{*}{ Variable } & \multirow{2}{*}{ Dimension } & \multirow{2}{*}{ Item } & \multicolumn{3}{|c|}{ National } & \multicolumn{3}{|c|}{ Foreign } & \multicolumn{3}{|c|}{ Employee } \\
\hline & & & Exp & Per & Exp-Per & Exp & Per & Exp-Per & Exp & Per & Exp-Per \\
\hline \multirow{9}{*}{ Expectations } & \multirow{4}{*}{ Tangibility } & E1 & 0.955 & & 0.784 & 0.998 & & 0.848 & 0.996 & & 0.818 \\
\hline & & E2 & 0.941 & & 0.803 & 0.998 & & 0.860 & 0.992 & & 0.806 \\
\hline & & E3 & 0.933 & & 0.835 & 0.999 & & 0.860 & 0.996 & & 0.823 \\
\hline & & E4 & 0.966 & & 0.854 & 0.999 & & 0.872 & 0.992 & & 0.804 \\
\hline & \multirow{5}{*}{ Reliability } & E5 & 0.922 & & 0.801 & 0.999 & & 0.860 & 0.980 & & 0.847 \\
\hline & & E6 & 0.933 & & 0.796 & 0.999 & & 0.871 & 0.993 & & 0.820 \\
\hline & & E7 & 0.947 & & 0.795 & 0.999 & & 0.869 & 0.989 & & 0.829 \\
\hline & & E8 & 0.922 & & 0.806 & 0.999 & & 0.866 & 0.993 & & 0.828 \\
\hline & & E9 & 0.945 & & 0.846 & 0.999 & & 0.862 & 0.991 & & 0.814 \\
\hline
\end{tabular}

Note: Exp-expectations, Per-perceptions, Exp-Per-expectations and perceptions

Own elaboration 
Table 7. Components extracted by groups for estimated indices (continued)

\begin{tabular}{|c|c|c|c|c|c|c|c|c|c|c|c|}
\hline \multirow[b]{2}{*}{ Variable } & \multirow[b]{2}{*}{ Dimension } & \multirow{2}{*}{$\begin{array}{l}\text { Ite } \\
\text { m }\end{array}$} & \multicolumn{3}{|c|}{ National } & \multicolumn{3}{|c|}{ Foreign } & \multicolumn{3}{|c|}{ Employee } \\
\hline & & & Exp & Per & $\begin{array}{l}\text { Exp- } \\
\text { Per }\end{array}$ & Exp & Per & $\begin{array}{l}\text { Exp- } \\
\text { Per }\end{array}$ & Exp & Per & $\begin{array}{l}\text { Exp- } \\
\text { Per }\end{array}$ \\
\hline \multirow{13}{*}{ Expectations } & \multirow{4}{*}{ Responsiveness } & E10 & 0.966 & & 0.877 & 0.999 & & 0.860 & 0.992 & & 0.828 \\
\hline & & E11 & 0.932 & & 0.764 & 0.999 & & 0.858 & 0.996 & & 0.848 \\
\hline & & $\mathrm{E} 12$ & 0.985 & & 0.735 & 0.999 & & 0.871 & 0.995 & & 0.844 \\
\hline & & E13 & 0.952 & & 0.877 & 0.999 & & 0.860 & 0.989 & & 0.837 \\
\hline & \multirow{4}{*}{ Assurance } & E14 & 0.954 & & 0.612 & 0.999 & & 0.868 & 0.990 & & 0.850 \\
\hline & & E15 & 0.985 & & 0.705 & 0.999 & & 0.870 & 0.994 & & 0.819 \\
\hline & & E16 & 0.978 & & 0.811 & 0.999 & & 0.872 & 0.990 & & 0.839 \\
\hline & & E17 & 0.984 & & 0.834 & 0.999 & & 0.867 & 0.992 & & 0.809 \\
\hline & \multirow{5}{*}{ Emphaty } & E18 & 0.936 & & 0.895 & 0.998 & & 0.867 & 0.992 & & 0.798 \\
\hline & & E19 & 0.924 & & 0.806 & 0.999 & & 0.874 & 0.992 & & 0.806 \\
\hline & & E20 & 0.946 & & 0.851 & 0.999 & & 0.876 & 0.993 & & 0.793 \\
\hline & & E21 & 0.957 & & 0.703 & 0.998 & & 0.881 & 0.993 & & 0.811 \\
\hline & & E22 & 0.952 & & 0.655 & 0.993 & & 0.908 & 0.942 & & 0.818 \\
\hline \multirow{22}{*}{ Perceptions } & \multirow{4}{*}{ Tangibility } & P1 & & 0.945 & 0.601 & & 0.992 & 0.507 & & 0.997 & 0.664 \\
\hline & & P2 & & 0.965 & 0.423 & & 0.993 & 0.502 & & 0.991 & 0.652 \\
\hline & & P3 & & 0.987 & 0.415 & & 0.998 & 0.507 & & 0.987 & 0.474 \\
\hline & & P4 & & 0.966 & 0.512 & & 0.998 & 0.509 & & 0.997 & 0.539 \\
\hline & \multirow{5}{*}{ Reliability } & P5 & & 0.988 & 0.689 & & 0.998 & 0.487 & & 0.995 & 0.511 \\
\hline & & P6 & & 0.995 & 0.478 & & 0.999 & 0.513 & & 0.997 & 0.533 \\
\hline & & P7 & & 0.956 & 0.605 & & 0.999 & 0.494 & & 0.997 & 0.530 \\
\hline & & P8 & & 0.933 & 0.599 & & 0.999 & 0.505 & & 0.994 & 0.542 \\
\hline & & P9 & & 0.995 & 0.575 & & 0.998 & 0.485 & & 0.998 & 0.579 \\
\hline & \multirow{4}{*}{ Responsiveness } & P10 & & 0.943 & 0.704 & & 0.998 & 0.481 & & 0.992 & 0.507 \\
\hline & & P11 & & 0.972 & 0.603 & & 0.997 & 0.454 & & 0.996 & 0.613 \\
\hline & & P12 & & 0.987 & 0.644 & & 0.998 & 0.489 & & 0.996 & 0.520 \\
\hline & & P13 & & 0.923 & 0.605 & & 0.999 & 0.496 & & 0.996 & 0.594 \\
\hline & \multirow{4}{*}{ Assurance } & P14 & & 0.956 & 0.512 & & 0.999 & 0.489 & & 0.995 & 0.513 \\
\hline & & P15 & & 0.985 & 0.423 & & 0.999 & 0.491 & & 0.995 & 0.619 \\
\hline & & P16 & & 0.962 & 0.722 & & 0.999 & 0.465 & & 0.997 & 0.551 \\
\hline & & P17 & & 0.932 & 0.634 & & 0.999 & 0.515 & & 0.997 & 0.599 \\
\hline & \multirow{5}{*}{ Emphaty } & P18 & & 0.944 & 0.605 & & 0.998 & 0.524 & & 0.995 & 0.576 \\
\hline & & P19 & & 0.978 & 0.553 & & 0.998 & 0.490 & & 0.989 & 0.657 \\
\hline & & P20 & & 0.945 & 0.520 & & 0.996 & 0.433 & & 0.993 & 0.613 \\
\hline & & P21 & & 0.925 & 0.511 & & 0.999 & 0.498 & & 0.996 & 0.557 \\
\hline & & P22 & & 0.923 & 0.576 & & 0.998 & 0.527 & & 0.991 & 0.611 \\
\hline
\end{tabular}

Note: Exp-expectations, Per-perceptions, Exp-Per-expectations and perceptions Own elaboration 


\section{Correlation matrix determinant, Eigenvalues, Variance, KMO and Bartlett's test}

For all cases, the determinant of the correlation matrix was greater than 0.00001 . Likewise, based on expectations, perceptions and both, the Components with eigenvalues greater than one were extracted. For all sets, the first Component was retained, which provides the maximum explanatory capacity of variance for national, foreign and employee groups. The indices had an explained variance capacity of among $92 \%$ and $99.58 \%$.

Table 8. Eigenvalue per Component and \% of variance explained

\begin{tabular}{|c|c|c|}
\hline Group & Eigenvalue & $\%$ variance \\
\hline \multicolumn{3}{|c|}{ Expectations } \\
\hline National & 21.512 & 98.439 \\
\hline Foreign & 21.907 & 99.576 \\
\hline Employee & 21.723 & 98.739 \\
\hline \multicolumn{3}{|c|}{ Perceptions } \\
\hline National & 21.512 & 98.439 \\
\hline Foreign & 21.907 & 99.576 \\
\hline Employee & 21.723 & 98.739 \\
\hline \multicolumn{3}{|c|}{ Expectations-Perceptions } \\
\hline National & 41.794 & 94.348 \\
\hline Foreign & 40.793 & 92.712 \\
\hline Employee & 41.826 & 95.059 \\
\hline
\end{tabular}

Regarding the viability of estimate Component Analysis on the data, considering $\alpha=$ 0.05 the Bartlett's test was significant for all cases ( $p$-value $=0.000$ ). Also, how it is well-known the KMO statistics, that is a measure of how suited a data set is for Component Analysis, suggest us that in all our cases the application is marvelous (see Table 10). In short, from the results obtained from the application of the KMO index as well as the Bartlett's test, the viability is evidenced from the data collected.

Table 9. KMO index and Bartlett's test (p-values)

\begin{tabular}{|c|c|c|c|c|c|c|}
\hline & \multicolumn{2}{|c|}{ Expectations } & \multicolumn{2}{c|}{ Perceptions } & \multicolumn{2}{c|}{ Expectations-Perceptions } \\
\hline Group & KMO & T. Bartlett & KMO & T. Bartlett & KMO & T. Bartlett \\
\hline National & 0.953 & 0.000 & 0.912 & 0.000 & 0.937 & 0.000 \\
\hline Foreigner & 0.985 & 0.000 & 0.986 & 0.000 & 0.993 & 0.000 \\
\hline Employee & 0.973 & 0.000 & 0.955 & 0.000 & 0.966 & 0.000 \\
\hline
\end{tabular}

It is worth mentioning that although theoretically it was not need to estimate the Cronbach's alpha coefficient, given that we are using the same models and items that have been tested before (Parasuraman et al., 1985; Frost and Khumar, 2000), they were greater or equal than 0.7 for every group. For the indices of expectations, there are high loads, which foresees that the samples under study expect a significant level of quality to be received prior to the occupation of the service in the lodge category establishments. As regards national and foreign tourists, the expected service implies a high standard in the 5 qualities referred to in the SERVQUAL model, while for employees, the same phenomenon occurs in the INTSERVQUAL model.

In relation to domestic tourists, the level of expectations is high, taking as highlights the values of 0.985 evidenced in two dimensions: responsiveness (E12) and assurance (E15), 
which are considered relevant at the time of opting for a hotel lodge service. Regarding foreign tourists, there is a higher weighting that scores 0.999 with respect to the expectations of the quality of service to be offered in lodges, this rating is distributed in the dimensions of tangibility (E3 and E4), reliability (E5 - E9), responsiveness (E10 - E13), assurance (E14 - E17) and empathy (E19 and E20). In the case of employees, the expectations analysis was evidenced in a score of 0.996 reflected in the dimensions of tangibility (E1 and E3) and responsiveness (E11). Finally, the strategies for improving the quality of service focus on intangible aspects, facing its importance on the understanding of specific customer needs, which suggests the establishment of continuous staff training programs, incentive generation and implementation of an adequate work environment in order to strengthen and understand exclusively the needs that the tourist, as well as the employee, have around the services offered by the lodges.

In the same way, for the indices of perceptions, in the case of national tourists, the highest score obtained is 0.995 corresponding to the reliability dimension (P6), which denotes that the quality of the service obtained lies in the level of fulfillment of the offer promise, that is, how much truthful was his dedication and attention. For foreign tourists, a pattern similar to that presented in expectations was followed as they managed to perceive high standards of service quality, reflected in a score of 0.999 in the dimensions of reliability (P6 - P8), responsiveness (P13), assurance (P14 - P17) and empathy (P21). These values denote that foreign tourists have perceived parity in terms of expectations and perceptions of the quality of the service, since the expected and received level of it has similar characteristics. Finally, for employees, the criterion with the highest score is 0.998 evidenced in the reliability dimension (P9). Thus, after having occupied the services of these establishments, the charges generated present a high standard of qualification, evidencing an adequate management of the quality of service provided internally and externally. The strategies for improving the quality of service are directed to the understanding of specific needs of the client, for this it is suggested to generate ex post loyalty, feedback, promotional campaigns and engagement strategies that allow optimize the conditions of the service that was offered.

Regarding the measurement index of both collections of variables, in relation to national tourists, the level of quality of service as a whole had a maximum score of 0.895 located in the dimension of empathy (E18), which denotes that, in the global analysis of the quality of service prior to the offer received. The referred dimension plays an important role when evaluating the services to be received, focusing on intangible aspects (interactions) that the staff can receive in the lodges under study. In the case of foreign tourists, the highest score is located in the same way in the dimension of empathy (E22) with 0.908 , denoting a similar interest focused on the weighting of intangible values when evaluating the quality of the service. In the case of employees, the highest score is 0.947 located in the reliability dimension (E5), which shows that the quality of service that employees can receive in their workplaces depends on the level of trust they expect to receive from their employers. Its structure suggests generating loyalty strategies ex ante and ex post for a continuous improvement of the quality of service in the lodges. For this, since the administration corresponds the establishment of a weighted schedule of monthly activities that involves actions to identify new market niches, build loyalty and generate experiences for potential customers. 


\section{CONCLUSIONS}

Considering the theoretical implications of the present research, the review of the literature on the quality of service in the area of hospitality and tourism, allowed us to denote an application level of several models to measure and evaluate the processes that aim to improve the supply generated in these fields. Much of the studies have been applied in Europe and Asia, with a temporality of at least 10 to 15 years (Qarasgia, 2018; Ertürk, 2019; Tsang et al., 2012; Górka-Chowaniec, 2018; Kahl et al., 2019), this suggests a stagnation of research in Latin America. In a nutshell, regarding contributions to theory what is new in this work in relation to the results of previous ones are the following: both instruments were applied simultaneously, where Latin American lodges were considered; new relations among items were found and other were confirmed; indices were estimated through PCA taking into account expectations, perceptions and both, which are useful to understand the importance of the main variables. Now we give more details about them.

In relation to the research carried out, the segment of national or foreign tourists comprises $95 \%$ of analysis, which was carried out through the SERVQUAL model, denoting a preferential use of it when analyzing the quality of the service exogenously, adopting criteria of familiarity in the analysis and interpretation of data obtained for the case studies found in the literature; while the segment of employees is estimated at $5 \%$, verifying a marginal contribution in analyzing the criterion of the quality of service generated for this last segment, through the application of the INTSERQVUAL model, denoting a limited interest in its application or a possible lack of knowledge of the benefits of the model for case studies that imply analyzing the quality of the service endogenously, that is, seen from the sector of the employees.

It is worth mentioning that, from the correlations found in this research, it is evident that there are significant correlated items within the same dimension (intra) and related items taken from different dimensions (inter) both not registered in the literature. For instance, into the expectation's variables, in the case of national tourists, the correlated items within the same dimension, appear in tangibility, reliability and empathy, and those between dimensions show only a tangibility-reliability relationship. Meanwhile, for foreign tourists, there is evidence of relationships between the items of tangibility and reliability, as well as a relationship between responsiveness-reliability denoted between dimensions. Finally, for employees there are new relationships in the items of tangibility, reliability and empathy, and similarly, new contributions between reliability-security, reliability-responsiveness and responsiveness-empathy. Overall, for the perception's variables new relationships are observed as well. In theoretical terms, they could be new considerations for the existing literature, and in practical terms, they could represent certain guides for lodge decision makers.

In a global way, it can be affirmed that this research allowed to verify that some correlations found are similar to those located in previous studies, considering that, its results are allocated in different contexts to the present in Ecuador. In particular, according to the results obtained from the application of the SERVQUAL model, significant correlations were obtained in the variables expectations and perceptions for the national and foreign tourist, of which some have been referred in the literature. Likewise, we identify new associations, which are part of the SERVQUAL model, both national and foreign tourists. In the case of employees, through the application of the INTSERVQUAL model, new correlations were also found, thus 
allowing to generate contributions in the construction of indices for the measurement of the quality of service for lodge-category hotels. It shows that this research is a pioneer in the quantitative analysis of the quality of service in lodge category establishments in Latin America.

Through the application of the KMO and Bartlett statistical tests, it is clear that the application of PCA in all the segments studied is relevant. With PCA, new components could be obtained for the design of indices, considering national tourists, foreigners and employees based on expectations and perceptions of the quality of service. In this way, nine Principal Components were obtained according to expectations, perceptions and both, respectively. The application of PCA demonstrated a high explanatory capacity, reflected in loads in a range of 0.49 and 0.99 based on the results for the SERVQUAL and INTSERVQUAL questionnaires.

On the other hand, the practical implications are attributed to exogenous variables such as conflict of interest, time of applicability of questionnaires and priority in other activities, seasonality of the tourist activity, location, organizational culture and research financing as inductive factors when generating the study; therefore, the lodge managers should keep them in mind when evaluating the quality of service; therefore, it is possible to identify the level of incidence that each variable of the quality of service offered has in relation to the expectations and perceptions of national and foreign tourists and of the employee who must incur special attention to be improved. The indexes generated allow them to be management tools to punctually identify the variable that requires attention and propose solutions for its continuous improvement.

The appropriate application of the indices obtained aims to generate in the lodge managers processes of continuous improvement to increase the level of service quality in their establishments, before this, it is important to consider the cultural and climatic context in which it operates, where the expectations generated by the client are important, but above all the perception of the service that he receives. Among the practical solutions for lodge managers, ease of decision-making, minimization of financial risks by operational areas, optimization of supplies and prioritization of staff attention are considered.

Certain limitations at the time of conducting the research must be taken into account, considering the interpretation of results and conclusions generated from them. Being a sector study and specific geographical specifications, the generalization of the numerical values of the indices may not be applicable to other scenarios, but comparable. As this research was carried out in the Sierra and Amazon of Ecuador, the weather factor has proved to be a relevant indicator at the time of gathering pertinent and timely information, presenting favorable conditions around climate temperature, topography, relative humidity, rain and sunlight. However, a challenge is anticipated when hypothesizing if these weather conditions vary, forecasting limitations when obtaining the necessary data for the development of the present study. For future research projects given the regular presence of unexpected phenomena, such as telluric movements, floods, volcanic eruptions or new pandemics in Ecuador, it would be recommended to coordinate actions with the Geophysical Institute of the National Polytechnic School, the Ecuadorian Institute of Hydraulic Resources (INERHI) and the Ecuadorian Health Ministry to identify the appropriate conditions that allow a normal execution of the study. 
We have two main future lines of research: a) it is considered appropriate to carry out a longitudinal approach with monthly periodicity in several categories of hotel establishments, in order to obtain service quality measurement indices focused on particular cases. It is suggested to be applied according to the following factors: seasonality of the demand, time of application of the questionnaires, language, level of knowledge of each reagent and ability to explain to the respondent. We also consider necessary b) to propose modifications to both instruments to cope the new reality derived by the COVID-19 pandemic. That is, nowadays there are not any point that evaluate the service quality given the pandemic, and a certification items with international standards could be mandatory to give certainty of a safe destination to new tourists flows.

This research aims to be an opportunity to maintain a personalized interaction between all the actors that make up the lodge service, generating constant feedbacks. It is thought that this could boost greater productivity and conceive competitive advantages over the different hotel categories in Ecuador. When applying statistical indices in the measurement of the quality of service, a different perspective is opened, where the qualitative analysis of the quality has been by tradition applied in lodging accommodation; therefore, it is likely that a new concept to be applied for the evaluation and improvement of the service that is intended to satisfy both the tourist and the employee, when the latter was not considered at the time of defining criteria to analyze the quality of service is foreseen. Finally, currently the processes of evaluation of the quality of service are framed in an international context, which has been adapted to the Ecuadorian circumstances. So, this research has been suggested as domestic competitive management model as well as an essential instrument for the establishment of a service quality management policy.

\section{REFERENCES}

Abdi, H., and Williams, L. (2010). Principal component analysis. Wiley interdisciplinary reviews: computational statistics, 2(4), 433-459.

Al-Ababneh, M. (2015). Employees' Service Innovation Behavior and New Service Development in Four-and Five-Star Hotels. International Journal of Tourism and Hospitality Reviews, 1(1), 13-22.

Albattat, A., and Romli, S. (2017). Determining visitors' repetition by using SERVQUAL dimensions in attraction parks: A case from Kuala Lumpur, Malaysia. International Journal of Applied Business and Economic Research, 15, 351-372.

Anderson, E. (1973). Consumer dissatisfaction: The effect of disconfirmed expectancy on perceived product performance. Journal of marketing research, 10(1), 38-44.

Bartlett, S. (1937). Tests of significance in factor analysis. British Journal of statistical psychology, 3(2), 77-85.

Bouranta, N., Chitiris, L., and Paravantis, J. (2009). The relationship between internal and external service quality. International Journal of Contemporary Hospitality Management.

Cardozo, N. (1965). An experimental study of customer effort, expectation, and satisfaction. Journal of marketing research, 2(3), 244-249. 
Chan, C. S., Liu, Y., and Li, C. Y. (2019). Expectation-Perception Evaluation of Theme Park Service Quality in Zhengzhou Fantawild, China. Journal of Park \& Recreation Administration, 37(2).

Chen, W. J. (2013). Factors influencing internal service quality at international tourist hotels. International Journal of Hospitality Management, 35, 152-160.

Cuadras, M. (2020) Nuevos Métodos de Análisis Multivariante. CMC Editions, Barcelona.

Donne, K. (2009). ADVENTUREQUAL: An extension of the SERVQUAL conceptual gap model in young people's outdoor adventure. International Journal of Sport Management and Marketing, 6(3), 253-276.

Ertürk, M. (2019). Measurement of Service Quality of Hotels in TRNC: SERVQUAL Model. Studies, 1(3), 35-42.

Fotiadis, A. K., and Vassiliadis, C. A. (2016). Service quality at theme parks. Journal of Quality Assurance in Hospitality \& Tourism, 17(2), 178-190.

Frochot, I., and Hughes, H. (2000). HISTOQUAL: The development of a historic houses assessment scale. Tourism management, 21(2), 157-167.

Frost, F., and Kumar, M. (2000). INTSERVQUAL-an internal adaptation of the GAP model in a large service organization. Journal of Services Marketing, 14(5), 358-377.

Górka-Chowaniec, A. (2018). Assessment of the quality of service in the catering industry as an important determinant in escalating the level of consumer confidence. European Journal of Service Management, 25, 99-107.

Grönroos, C. (1984). A service quality model and its marketing implications. European Journal of marketing, 18(4), 36-44.

Heung, V., and Wong, M. (1997). Hotel service quality in Hong Kong: A study of tourists' expectations. Journal of Vacation Marketing, 3(3), 264-271.

Hotelling, H. (1933). Analysis of a complex of statistical variables into principal components. Journal of Educational Psychology, 24(6), 417-441.

Kahl, C., Kaishantayeva, M. D., Margulanovna, A., and Kashakbay, A. K. B. (2019). Perception of Service Quality in Restaurant Industry in Kazakhstan. Case Study of Almaty Restaurant. Zeszyty Naukowe Politechniki Częstochowskiej Zarzq̨dzanie, 36,16-33.

Khan, M., and Su, K. (2003). Service quality expectations of travelers visiting Cheju Island in Korea. Journal of Ecotourism, 2(2), 114-125.

Kim, G. J. (2014). Applying service profit chain model to the Korean restaurant industry. International Journal of Hospitality Management, 36, 1-13.

Kouthouris, C., and Alexandris, K. (2005). Can service quality predict customer satisfaction and behavioral intentions in the sport tourism industry? An application of the SERVQUAL model in an outdoors setting. Journal of Sport \& Tourism, 10(2), 101-111.

Legendre, P., and Legendre, L. (2012). Numerical ecology, 24. Elsevier.

Lewis, B. (1989). Quality in the Service Sector - A Review, International Journal of Bank Marketing. 
Lewis, R., and Booms, B. (1983). The marketing aspects of service quality. Emerging perspectives on services marketing, 65(4), 99-107.

Markovic, S., Raspor Jankovic, S., and Komšić, J. (2013). Museum service quality measurement using the HISTOQUAL Model. In 2nd International Scientific Conference Tourism in Southeast Europe.

Mey, L., Akbar, A., and Fie, D. (2006). Measuring service quality and customer satisfaction of the hotels in Malaysia: Malaysian, Asian and non-Asian hotel guests. Journal of Hospitality and Tourism Management, 13(2), 144-160.

MINTUR (2015) Reglamento Oficial N 465. Quito. Ecuador. 24 de marzo del 2015.

Mola, F., and Jusoh, J. (2011). Service quality in Penang hotels: A gap score analysis. World Applied Sciences Journal, 12(1), 19-24.

Moore, D. (1987). Outclass the competition with service distinction. Mortgage Banking, 47(11), 24-32.

Moussa, H., Mohamed, A. E. D., and Ahmed, S. (2012). The relationship between INTSERVQUAL \& EXTSERVQUAL in Full-service restaurants: a comparative study between Domestic foreign restaurants. Journal of Association of Arab Universities for Tourism and Hospitality, 9(1), 1-14.

Nadiri, H., and Hussain, K. (2005). Perceptions of service quality in North Cyprus hotels. International Journal of Contemporary Hospitality Management, 17(6), 469480 .

Nowacki, M. M. (2005). Evaluating a museum as a tourist product using the SERVQUAL method. Museum Management and Curatorship, 20(3), 235-250.

Ntavitavian, I. (2020). Exploration and Analysis of Employee Satisfaction, Customer Satisfaction and Financial Performance as Determinants of a Hotel Success. School of Economics, Business administration \& Legal Studies, A thesis submitted for the degree of Master of Science (MSc) in Hospitality and Tourism Management

Pantouvakis, A. (2011). Internal service quality and job satisfaction synergies for performance improvement: Some evidence from a B2B environment. Journal of Targeting, Measurement and Analysis for Marketing, 19(1), 11-22.

Parasuraman, A., Zeithaml, V., and Berry, L. (1985). A conceptual model of service quality and its implications for future research. Journal of Marketing, 4(4): 41-50.

Parasuraman, A., Zeithaml, V., and Berry, L. (1988). SERVQUAL: A multiple-item scale for measuring consumer perc. Journal of retailing, 64(1), 12.

Pearson, K. (1901). LIII. On lines and planes of closest fit to systems of points in space. The London, Edinburgh, and Dublin Philosophical Magazine and Journal of Science, 2(11), 559-572.

Qarashia, Y. A. (2018). Service Experience \& Expectations of Saudi Arabia Domestic Tourists in the Lodging Sector. Rochester Institute of Technology. 
Qu, H., and Tsang, N. (1998). Service quality gap in China's hotel industry: A study of tourist perceptions and expectations. Journal of Hospitality and Tourism Research, 22(3), 252267.

Saleh, F., and Ryan, C. (1991). Analyzing service quality in the hospitality industry using the SERVQUAL model. Service Industries Journal, 11(3), 324-345.

Schober, P., Boer, C., and Schwarte, L. A. (2018). Correlation coefficients: appropriate use and interpretation. Anesthesia \& Analgesia, 126(5), 1763-1768.

Shi, J., and Su, Q. (2007). Evaluation of hotel service quality based on customer satisfaction. In 2007 International Conference on Service Systems and Service Management (pp. 15). IEEE.

Shonk, D. J., and Chelladurai, P. (2008). Service quality, satisfaction, and intent to return in event sport tourism. Journal of sport management, 22(5), 587-602.

Stefano, N., Casarotto Filho, N., Barichello, R., and Sohn, A. (2015). A fuzzy SERVQUAL based method for evaluated of service quality in the hotel industry. Procedia CIRP, 30, 433438.

Sunil, M., Shobharani, H., Mathew, A., and Rose, E. (2018). Validation of SERVQUAL Model in Star Hotels Pertaining to Bengaluru City. Asian Journal of Management.

Thibaut, W. (2017). The social psychology of groups. Routledge.

Tsang, N. K., Lee, L. Y., Wong, A., and Chong, R. (2012). THEMEQUAL-Adapting the SERVQUAL scale to theme park services: A case of Hong Kong Disneyland. Journal of Travel \& Tourism Marketing, 29(5), 416-429.

Villardón, V. (2002). Análisis de componentes principales. Cataluña: UOC, Departamento de Estadística, 32.

White, C., and Rudall, L. (1999). INTERSERVQUAL: an investigation of the dimensions and measurement of internal service quality in the hospitality industry. Australian Journal of Hospitality Management, 6(2), 13-13.

Wittmer, A. (2005). Internal Service Systems and Cultural Differences: An Exploratory Study of Switzerland, Australia, and Singapore (Doctoral dissertation, University of St. Gallen).

Yeh, S. C., and Chu, P. (2009). Exploring internal and external service chains of electronic government services. Journal of Service Quality, 4(1), 1-14.

Zeithaml, V., Parasuraman, A. and Berry, L. (1985). Problems and strategies in services marketing. Journal of Marketing, 49, 33-46.

\section{CONTRIBUCIONES DE LOS AUTORES:}

Autor 1: Concepción original del trabajo, adquisición de los datos obtenidos en campo, redacción del contenido, aprobación final de la versión a publicar.

Autor 2: Diseño muestral y análisis estadístico, Interpretación de los datos, revisión crítica del contenido, aprobación final de la versión a publicar. 


\section{AGRADECIMIENTOS:}

Los autores agradecen los valiosos comentarios y sugerencias de los revisores anónimos, así como del editor de la revista. Asimismo, al Consejo Nacional de Ciencia y Tecnología de México (CONACYT) por el apoyo brindado a través de becas de investigación. Con ellas se pudo financiar parte de este proyecto. 


\section{Annexes}

\begin{tabular}{|c|c|c|c|c|c|c|c|c|}
\hline \multicolumn{9}{|c|}{ SERVQUAL instrument } \\
\hline \multirow{2}{*}{ Variables } & \multirow{2}{*}{ Dimensions } & \multicolumn{7}{|c|}{ Scale } \\
\hline & & 1 & 2 & 3 & 4 & & & 7 \\
\hline \multirow{27}{*}{ Expectations } & Tangibility & & & & & & & \\
\hline & Excellent lodges will have modern- looking equipment (E1) & & & & & & & \\
\hline & The physical facilities at an excellent lodge will be visually appealing (E2) & & & & & & & \\
\hline & Employees of an excellent lodge will be neat-appearing (E3) & & & & & & & \\
\hline & $\begin{array}{l}\text { Materials associated with the service will be visually appealing in an } \\
\text { excellent lodge (E4) }\end{array}$ & & & & & & & \\
\hline & Reliability & & & & & & & \\
\hline & $\begin{array}{l}\text { When an excellent lodge promises to do something by a certain time, it will } \\
\text { do so (E5) }\end{array}$ & & & & & & & \\
\hline & $\begin{array}{l}\text { When you have a problem, excellent lodges will show a sincere interest in } \\
\text { solving it (E6) }\end{array}$ & & & & & & & \\
\hline & Excellent lodges will perform the service right the first time (E7) & & & & & & & \\
\hline & $\begin{array}{l}\text { Excellent lodges will provide their service at the time they promises to do so } \\
\text { (E8) }\end{array}$ & & & & & & & \\
\hline & Excellent lodges will insist on error-free records (E9) & & & & & & & \\
\hline & Responsiveness & & & & & & & \\
\hline & $\begin{array}{l}\text { Employees of excellent lodges will tell you exactly when services will be } \\
\text { performed (E10) }\end{array}$ & & & & & & & \\
\hline & Employees of excellent lodges will give you prompt service (E11) & & & & & & & \\
\hline & Employees of excellent lodges will be always be willing to help you (E12) & & & & & & & \\
\hline & $\begin{array}{l}\text { Employees of excellent lodges will be never too busy to respond to your } \\
\text { requests (E13) }\end{array}$ & & & & & & & \\
\hline & Assurance & & & & & & & \\
\hline & $\begin{array}{l}\text { The behavior of employees of excellent lodges will instill confidence in } \\
\text { customers (E14) }\end{array}$ & & & & & & & \\
\hline & Customers of excellent lodges will feel safe in their transactions (E15) & & & & & & & \\
\hline & Employees of excellent lodges will be consistently courteous with you (E16) & & & & & & & \\
\hline & $\begin{array}{l}\text { Excellent lodges will give have the knowledge to answer your questions } \\
\text { (E17) }\end{array}$ & & & & & & & \\
\hline & Emphaty & & & & & & & \\
\hline & Excellent lodges will give you individual attention (E18) & & & & & & & \\
\hline & $\begin{array}{l}\text { Excellent lodges will have operating hours convenient to all their customers } \\
\text { (E19) }\end{array}$ & & & & & & & \\
\hline & Excellent lodges will have employees who give you personal attention (E20) & & & & & & & \\
\hline & Excellent lodges will have your best interest at heart (E21) & & & & & & & \\
\hline & Employees of excellent lodges will understand your specific needs (E22) & & & & & & & \\
\hline \multirow{6}{*}{ Perceptions } & Tangibility & & & & & & & \\
\hline & The lodge has modern looking equipment (P1) & & & & & & & \\
\hline & The lodge's physical facilities are visually appealing (P2) & & & & & & & \\
\hline & The lodge's employees are neat-appearing (P3) & & & & & & & \\
\hline & Materials associated with the service are visually appealing at the lodge (P4) & & & & & & & \\
\hline & Reliability & & & & & & & \\
\hline
\end{tabular}




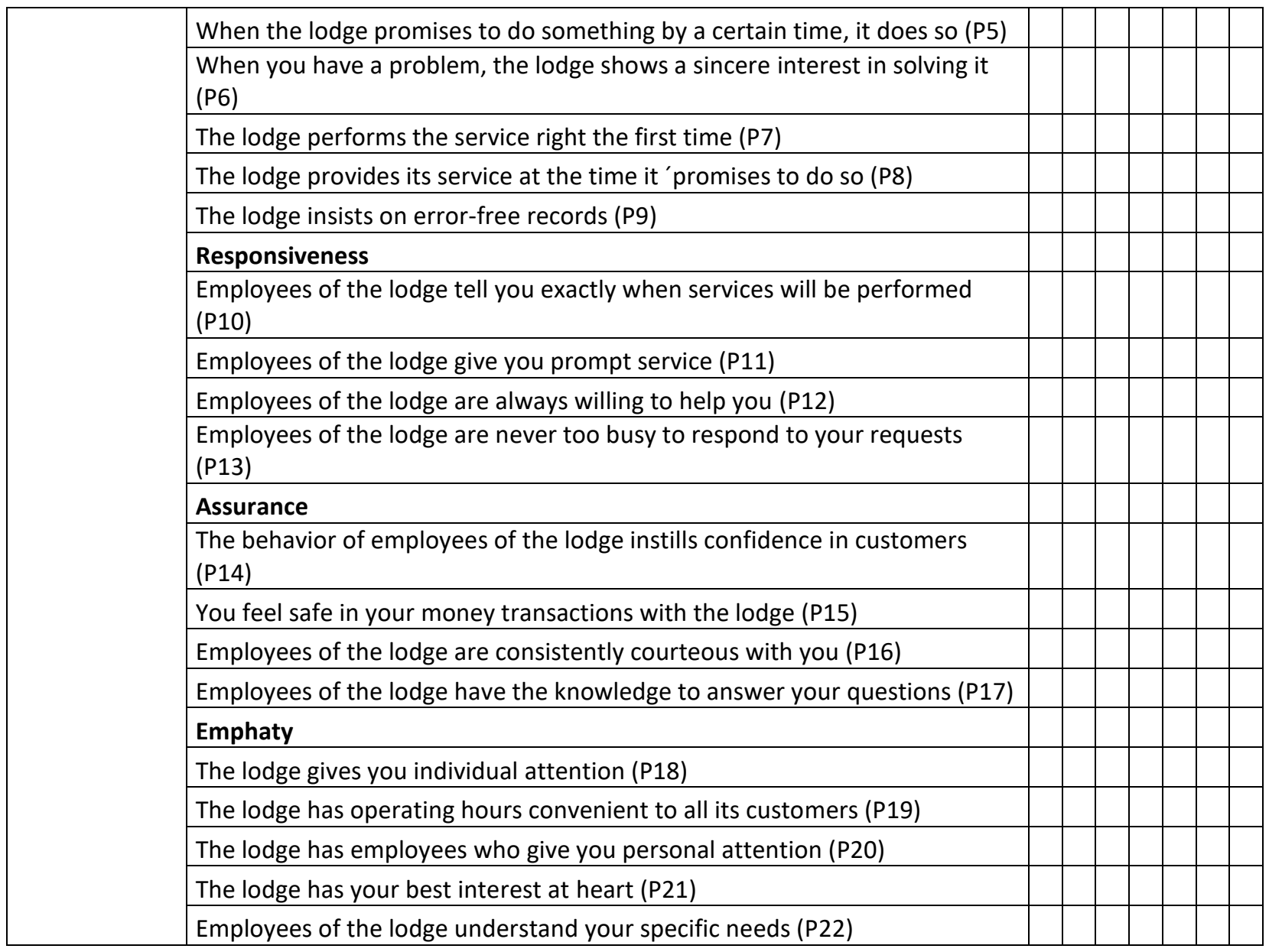

INTSERVQUAL instrument

\begin{tabular}{|c|c|c|c|c|c|c|c|c|}
\hline \multirow{2}{*}{ Variables } & \multirow{2}{*}{ Dimensions } & \multicolumn{7}{|c|}{ Scale } \\
\hline & & 1 & 2 & 3 & 4 & 5 & 6 & 7 \\
\hline \multirow{10}{*}{ Expectations } & Tangibility & & & & & & & \\
\hline & Internal service provider departments must have modern equipment (E1) & & & & & & & \\
\hline & $\begin{array}{l}\text { The facilities of the internal service provision departments must be visually } \\
\text { attractive (E2) }\end{array}$ & & & & & & & \\
\hline & $\begin{array}{l}\text { Employees of the internal services provision department must have a clean } \\
\text { professional appearance (E3) }\end{array}$ & & & & & & & \\
\hline & $\begin{array}{l}\text { Materials associated with the service (such as timesheets, bulletins, reports, } \\
\text { manuals or statements) should be visually appealing in the internal service } \\
\text { provision departments (E4) }\end{array}$ & & & & & & & \\
\hline & Reliability & & & & & & & \\
\hline & The services of the internal service provider must be provided as promised (E5) & & & & & & & \\
\hline & $\begin{array}{l}\text { If there is a problem, the internal service provider must show a sincere interest in } \\
\text { solving it (E6) }\end{array}$ & & & & & & & \\
\hline & The internal service provider must deliver its services correctly the first time (E7) & & & & & & & \\
\hline & The internal service provider must provide its services at the promised time (E8) & & & & & & & \\
\hline
\end{tabular}




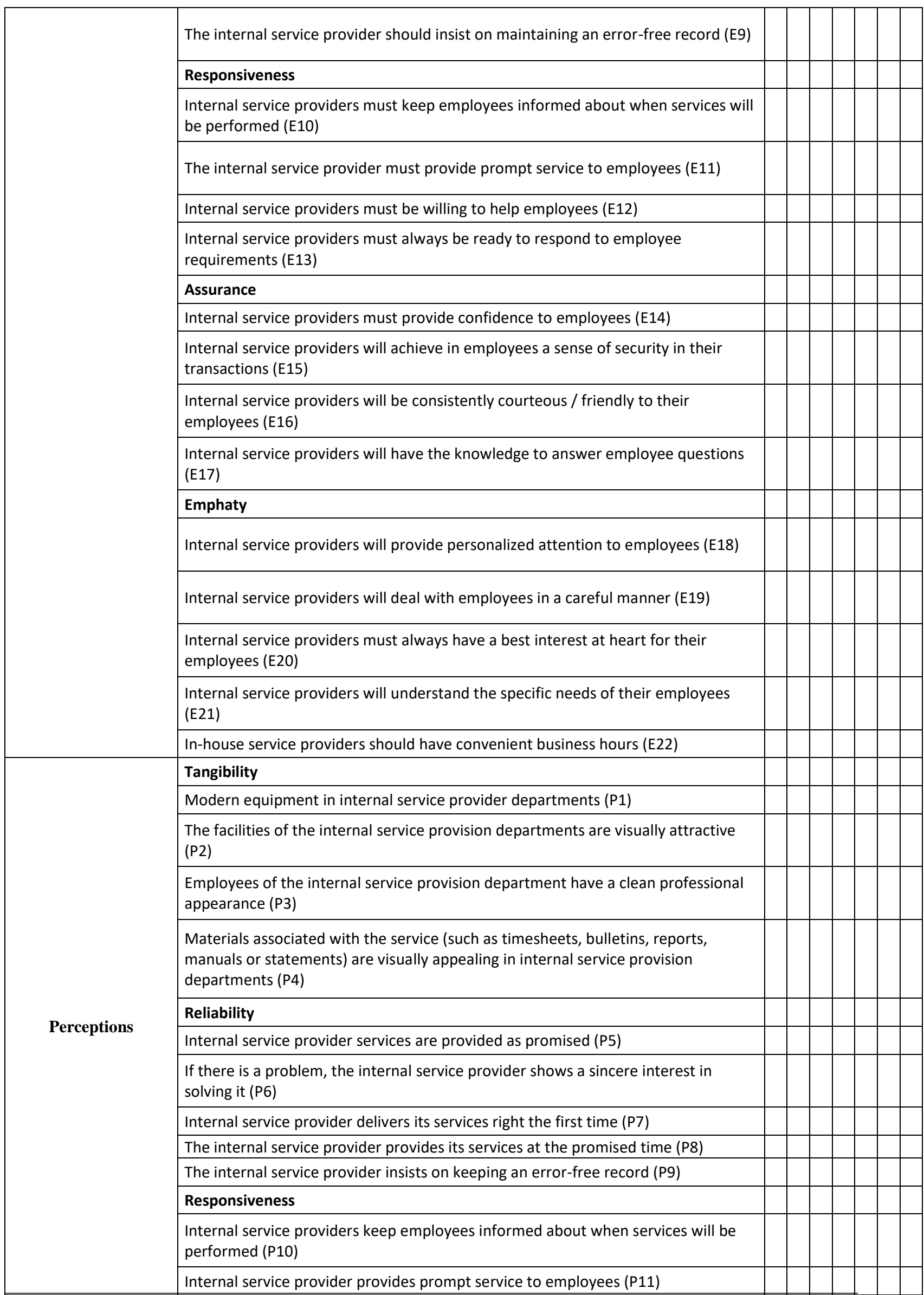




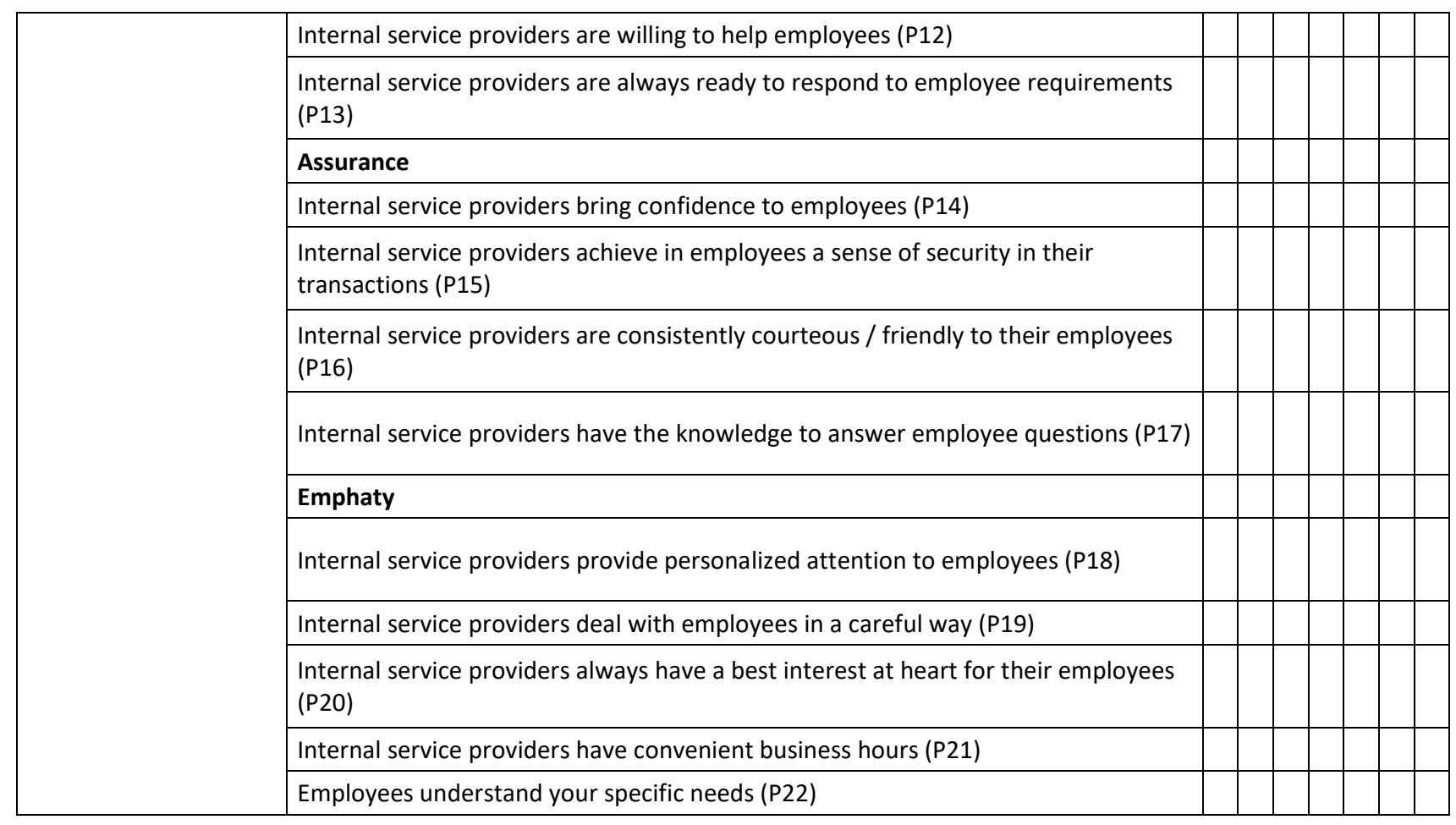

